\title{
PENGEMBANGAN MULTIMEDIA INTERAKTIF UNTUK PEMBELAJARAN IPS DI SEKOLAH DASAR MENGGUNAKAN MODEL DDD-E
}

\author{
Havizul \\ SDN 06 Pontianak Kota \\ Gg. Gunung Jati, Kec. Pontianak Kota, Pontianak \\ Alamat e-mail: havizul@gmail.com
}

\begin{abstract}
Abstrak
Tujuan penelitian ini adalah mengembangkan multimedia interaktif untuk pembelajaran IPS di Sekolah Dasar. Penelitian dilaksanakan di SDN 06 Pontianak Kota. Materi yang diangkat adalah tentang "Keragaman Suku Bangsa Dan Budaya Di Indonesia". Jenis penelitian yang digunakan adalah penelitian dan pengembangan (R\&D). Model desain instruksional yang digunakan adalah model DDD-E yang terdiri atas empat langkah, yaitu: (1) Decide, (2) Design, (3) Develop, dan (4) Evaluate. Teknik dan alat pengumpulan data menggunakan teknik observasi dengan alat lembar observasi dan teknik pengukuran dengan alat berupa tes. Hasil penelitian menunjukkan bahwa multimedia interaktif yang telah dikembangkan dapat meningkatkan efisiensi dan efektivitas pembelajaran serta hasil belajar siswa.
\end{abstract}

Kata Kunci: multimedia interaktif; pembelajaran IPS; model DDD-E;

\section{Abstract}

The purpose of this study was to develop an interactive multimedia for social science learning in elementary school. The study was conducted in SDN 06 Pontianak Kota. The topic discussed was about "Ethnic and Cultural Diversity in Indonesia". The type of research used was research and development $(R \& D)$. The instructional design model used was DDD-E model wich has four steps, namely: (1) Decide, (2) Design, (3) Develop, and (4) Evaluate. The data collection techniques and tools use direct observation techniques with observation sheet and measurement techniques with tests. The results of the study show that the interactive multimedia that has been developed can improve learning effeciency and effectiveness of students learning outcomes.

Keywords: interactive multimedia; social science learning; DDD-E model;

\section{PENDAHULUAN}

Siswa sekolah dasar di Indonesia umumnya dimulai pada usia 7 tahun dan berakhir pada usia 12 tahun. Menurut Jean Piaget dalam Asrori (2015:75-76), usia antara 7-11 tahun adalah usia seseorang yang berada dalam tahap operasional konkret, dimana pada tahap ini anak mulai menyesuaikan diri dengan realitas konkrit dan sudah mulai berkembang rasa ingin tahunya. Pada tahap ini, anak sudah dapat melakukan operasi mental untuk mengimajinasikan suatu bentuk benda tertentu yang diinginkan namun masih perlu bantuan dengan melihat bentuk benda aslinya. Sumber lain menyebutkan tahap operasional konkrit berada pada usia 
antara 7 atau 8 tahun hingga 11 atau 12 tahun, dan pada tahap tersebut anak telah memiliki kecakapan berpikir logis, akan tetapi hanya dengan benda-benda yang bersifat konkrit. Dari sini dapat diketahui bahwa siswa sekolah dasar mulai dari kelas 1 hingga 6, merupakan anak yang berada dalam tahap perkembangan operasional konkrit.

Umumnya mata pelajaran IPS memiliki topik-topik pelajaran yang abstrak, seperti halnya topik yang akan diangkat dalam penelitian ini yang berjudul “Keragaman Suku Bangsa Dan Budaya Di Indonesia”. Bahasan tentang topik ini akan sulit untuk dipahami oleh anak sekolah dasar jika pembelajarannya hanya mengandalkan cara verbal dan tekstual. Untuk membantu siswa memahami dengan baik materi yang diajarkan, maka disamping cara-cara yang verbal atau tekstual juga harus dibantu dengan pembelajaran yang visual dan interaktif. Sehingga, dengan melihat secara konkrit hal-hal yang sedang dibahas dalam materi pelajaran tersebut, para siswa yang notabene adalah anak dalam tahap operasional konkrit ini dapat mencerna dengan baik pesan-pesan yang terkandung dalam materi pelajaran yang sedang disampaikan oleh guru. Berdasarkan hal-hal yang telah dikemukakan tersebut, maka didapat rumusan masalah atau pertanyaan dalam penelitian ini adalah "bagaimana mengembangkan produk pembelajaran atau media pembelajaran yang dapat membantu siswa agar mudah memahami materi-materi pelajaran yang abstrak dalam pelajaran IPS, yaitu materi tentang Keragaman Suku Bangsa dan Budaya di Indonesia"

Salah satu cara yang dapat ditempuh untuk membantu anak pada tahap operasional konkrit agar dapat memahami materi pelajaran dengan baik dan mudah adalah dengan memanfaatkan media pembelajaran, sehingga dalam pembelajaran para siswa dapat terbantu baik secara visual, audio, maupun sajian animasi. Produk pembelajaran yang dimaksud disini terutama yang dapat menyajikan materi dengan baik secara visual sehingga dapat memudahkan siswa sekolah dasar memahami materi pelajaran, dan baik dari aspek audio dan tampilan animasi sehingga dapat menarik perhatian siswa. Tujuan dari penelitian ini adalah untuk mengembangkan produk pembelajaran yang dapat membantu siswa agar mudah memahami materi- 
materi pelajaran yang abstrak dalam pelajaran IPS, yaitu materi tentang Keragaman Suku Bangsa dan Budaya di Indonesia.

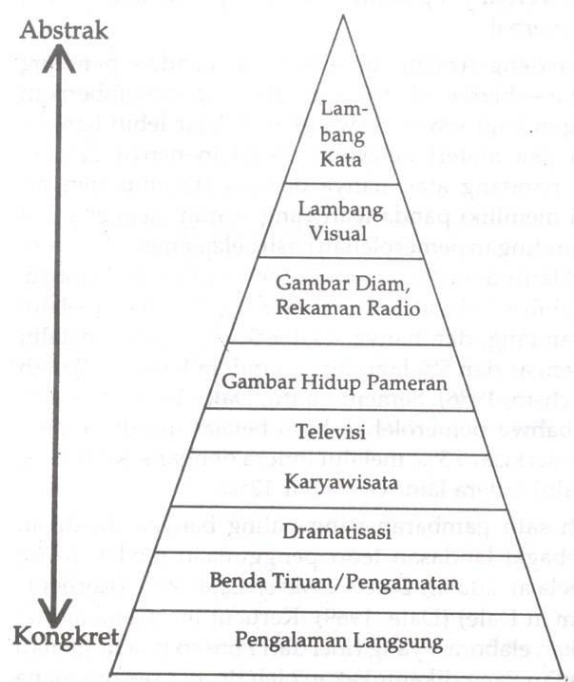

\section{Gambar 1. Kerucut Pengalaman Edgar Dale (Arsyad, 2016:14)}

Produk pembelajaran yang cocok untuk kebutuhan diatas adalah sebuah media pembelajaran berupa multimedia interaktif yang dapat menyajikan materi pelajaran secara konkrit. Multimedia ini harus dapat menyajikan materi pelajaran dengan mengedepankan aspek visual, dan didukung dengan unsur teks, audio dan animasi yang menarik. Kemudian multimedia tersebut dipadukan dengan metode pembelajaran kontekstual, sehingga akan dihasilkan suatu perangkat pembelajaran yang dapat memberikan pengalaman langsung kepada siswa dan sajian materi yang mengedepankan aspek visual. Diharapkan dengan media dan metode pembelajaran yang dikembangkan disini, pemerolehan belajar siswa meningkat secara signifikan.

Arsyad (2016: 10) menyatakan bahwa media pembelajaran adalah segala sesuatu yang dapat digunakan untuk menyampaikan pesan atau informasi dalam proses belajar mengajar sehingga dapat merangsang perhatian dan minat siswa dalam belajar. Arsyad (2016: 162) juga menyatakan bahwa definisi multimedia secara sederhana dapat diartikan sebagai lebih dari satu media, yang dapat berupa teks, grafik, animasi, suara dan video, terutama yang berbasis kendali komputer atau perangkat lunak. Arsyad (2016: 13) menyebutkan, Dale memperkirakan bahwa pemerolehan hasil belajar melalui indera pandang berkisar $75 \%$, melalui indera dengar sekitar 13\%, dan melalui indera lainnya sekitar 12\%. Sedangkan menurut 
Baugh dalam Achsin, kurang lebih 90\% hasil belajar seseorang diperoleh melalui indera pandang, 5\% dari indera dengar, dan 5\% lagi melalui indera lainnya. Pada gambar 1 diatas, menunjukkan tingkat keabstrakan suatu pesan, semakin tinggi tingkat keabstrakan pesan tersebut jika disampaikan ke dalam lambang-lambang. Jadi, dapat disimpulkan bahwa media pembelajaran yang baik, yang dalam penelitian ini berupa multimedia interaktif, adalah media pembelajaran yang dapat menyajikan materi secara visual dan interaktif, sehingga siswa dapat melihat secara konkrit sub-sub materi yang bersifat abstrak, dan siswa menjadi aktor utama yang terlibat langsung dalam pembelajaran.

\section{METODE}

Jenis penelitian ini adalah penelitian dan pengembangan atau research \& development (R\&D), atau sering kali hanya disebut dengan "pengembangan". Dilakukan di SDN 06 Pontianak pada semester ganjil tahun 2018. Subjek penelitian adalah siswa kelas V B. Model pengembangan yang digunakan untuk mengembangkan produk multimedia interaktif disini adalah model DDD-E. Untuk menguji efektifitas produk digunakan Uji T Sampel Berpasangan, kemudian dilanjutkan dengan perhitungan Effect Size. Model DDD-E terdiri atas empat tahapan, yaitu decide, design, develop, dan evaluate.

Decide, yaitu menentukan tujuan umum pembelajaran, menentukan bahan pembelajaran, dan melakukan penelitian awal. Pertama-tama adalah menentukan tujuan umum pembelajaran, kemudian dipilih bahan pembelajaran yang paling tepat digunakan dalam kegiatan pembelajaran untuk mencapai tujuan pembelajaran tersebut. Kemudian dilakukan penelitian awal yaitu mengidentifikasi kemampuan awal siswa dan menilai ketersedian sumber daya di sekolah, apakah siswa mampu menggunakan bahan pembelajaran tersebut atau tidak, jika tidak maka siswa dilatih untuk dapat menguasainya. Selanjutnya adalah menilai sumber daya yang tersedia di sekolah, apakah bahan pembelajaran tersebut tersedia di sekolah atau mendukung untuk diimplementasikan di sekolah tersebut. Hasil akhir (outcomes) dari tahap pertama ini adalah berupa rumusan tujuan umum pembelajaran, jenis bahan instruksional (multimedia) yang akan digunakan, dokumen hasil identifikasi 
kemampuan awal siswa, dan dokumentasi hasil identifikasi ketersediaan sumber daya di sekolah.

Design, yaitu merancang produk pembelajaran sebagai upaya untuk mewujudkan bahan pembelajaran yang telah ditentukan pada langkah decide. Produk pembelajaran yang akan dikembangkan dalam penelitian ini adalah multimedia interaktif untuk pembelajaran IPS di sekolah dasar. Langkah-langkah yang dilakukan diantaranya membuat flowchart, mendesain tampilan (interface), dan membuat storyboard. Hasil akhir (outcomes) dari tahap kedua ini adalah berupa blue print dari rancangan multimedia interaktif yang terdiri dari daftar konten multimedia, flowchart yang menggambarkan menu / sub menu multimedia, rancangan interface atau tampilan multimedia, dan storyboard.

Develop, yaitu mengembangkan multimedia interaktif, dimana hasil rancangan pada tahap design yang telah berbentuk blue print direalisasikan atau diimplementasikan menjadi produk nyata. Objek gambar, teks, audio, video, animasi, dan atau objek 2D/3D lainnya digabungkan menjadi satu sehingga tercipta sebuah produk multimedia interaktif yang siap digunakan dalam kegiatan pembelajaran IPS di sekolah.

Evaluate, yaitu evaluasi formatif yang dilakukan pada setiap tahapan dalam model DDD-E mulai dari tahap pertama decide, tahap kedua design, dan tahap ketiga develop. Pada tahap design, dilakukan evaluasi formatif terhadap kecocokan antara multimedia dengan tujuan pembelajaran dan hasil penelitian awal. Kemudian dilakukan evaluasi formatif pada hasil akhir dari tahap design, yaitu daftar konten, flowchart, storyboard, dan tampilan interface. Yang terakhir adalah dilakukan evaluasi formatif pada hasil akhir yang didapat dari tahap develop, yaitu evaluasi terhadap elemen-elemen multimedia. Setelah tahap evaluasi selesai dilakukan, maka hasil dari evaluasi formatif yang diperoleh ini dijadikan sebagai masukan untuk merevisi luaran / hasil akhir (outcomes) dari setiap tahapan decide, design, maupun develop tersebut.

Produk multimedia interaktif untuk pembelajaran IPS di sekolah dasar ini dibuat menggunakan Ms. Power Point 2013. Komponen utama dalam multimedia ini adalah elemen-elemen visual dan animasi, didukung oleh elemen teks dan audio. 
Untuk mengaplikasikannya dalam pembelajaran membutuhkan ketersediaan infocus untuk memproyeksikan materi dari multimedia dan laptop sebagai perangkat keras yang menjalankan multimedia interaktif. Kemudian, dalam pembelajaran, produk multimedia ini dipadukan dengan metode pembelajaran kontekstual, sehingga tercipta suasana pembelajaran yang berpusat pada siswa, guru sebagai fasilitator, siswa terlibat langsung dan mendapatkan pengalaman belajar yang berkesan. Selama proses pembelajaran, siswa akan berada dalam lingkungan belajar kontekstual yang mengandung tujuh unsur, yaitu: (1) konstruktivistik, (2) inkuiri, (3) questioning, (4) learning community, (5) pemodelan, (6) reflektif, dan (7) authentic assessment.

Teknik dan alat pengumpulan data yang digunakan adalah teknik observasi langsung dengan alat lembar observasi, teknik dokumenter dengan alat dokumentasi, dan teknik pengukuran dengan alat berupa tes. Sedangkan teknik analisis data yang digunakan adalah statistik deskriptif dan statistik inferensial. Pada analisis data dengan statistik inferensial digunakan analisis statistik parametris yaitu uji t sampel berpasangan. Nilai hasil pre-test dan post-test siswa dianalisis normalitas datanya, kemudian dilakukan ujit t untuk mengetahui pengaruh produk multimedia interaktif terhadap pemerolehan belajar siswa, dan dilanjutkan dengan perhitungan effect size untuk mengetahui besarnya pengaruh yang diberikan oleh produk multimedia tersebut.

\section{HASIL DAN PEMBAHASAN}

Pada tahap decide yang telah dilakukan dalam penelitian ini, ditentukan tujuan pembelajaran berdasarkan RPP, yaitu: (1) siswa mampu menunjukkan persebaran daerah asal suku bangsa di Indonesia melalui peta, (2) siswa mampu mengidentifikasi keragaman budaya yang terdapat di Indonesia, dan (3) siswa mampu mengembangkan sikap menghormati dan menghargai keragaman suku bangsi di Indonesia. Kemudian pada penelitian awal, identifikasi kemampuan awal siswa menunjukkan: (1) secara umum, siswa memiliki kemampuan rata-rata anak sekolah dasar kelas V, (2) secara khusus, siswa masih banyak yang mendapatkan nilai murni di bawah KKM dalam pembelajaran ini, dimana sekitar 70-80 \% siswa 
di kelas V B mendapatkan nilai ulangan harian di bawah KKM, (3) siswa merupakan anak generasi 4.0 yang terbiasa dengan penggunaan perangkat digital dan mampu beradaptasi dengan cepat pada perangkat-perangkat digital yang berbasis komputer seperti sistem operasi android, windows, dan macintosh, dan (4) siswa merupakan anak dalam tahap perkembangan operasional konkrit, yang mana membutuhkan pembelajaran yang banyak mengandung unsur visual, interaktif dan pengalaman langsung. Dari hasil menentukan tujuan pembelajaran dan identifikasi kemampuan awal siswa ini, dilakukan pemilihan bahan instruksional yang cocok untuk pembelajaran IPS ini, yaitu berupa multimedia interaktif yang simpel dan dinamis, maka pilihan yang tepat adalah multimedia yang berbasiskan microsoft office power point. Selanjutnya mengidentifikasi ketersediaan sumber daya di sekolah, apakah mendukung untuk pengimplementasian multimedia interaktif atau tidak. Dari hasil identifikasi sumber daya yang tersedia di sekolah, diperoleh informasi: (1) di SDN 06 Pontianak Kota tersedia infocus, (2) di SDN 06 Pontianak Kota tersedia laptop yang dapat digunakan untuk keperluan belajar dan administrasi sekolah, (3) rata-rata guru memiliki laptop sendiri yang jika terpakasa dapat mereka gunakan untuk kepentingan pembelajaran di sekolah. Dari hasil identifikasi yang terakhir ini, diperoleh kesimpulan bahwa penerapan multimedia interaktif berbasis microsoft office power point sebagai media pembelajaran IPS di SDN 06 Pontianak Kota ini akan dapat dilakukan secara optimal karena sesuai untuk mencapai tujuan pembelajaran, siswa memiliki kemampuan yang memadai, dan sumber daya sekolah juga mendukung.

Pada tahap design yang telah dilakukan dalam penelitian ini, dihasilkan rancangan flowchart, tampilan (interface), dan storyboard, seperti diperlihatkan dalam gambar-gambar dibawah ini: 


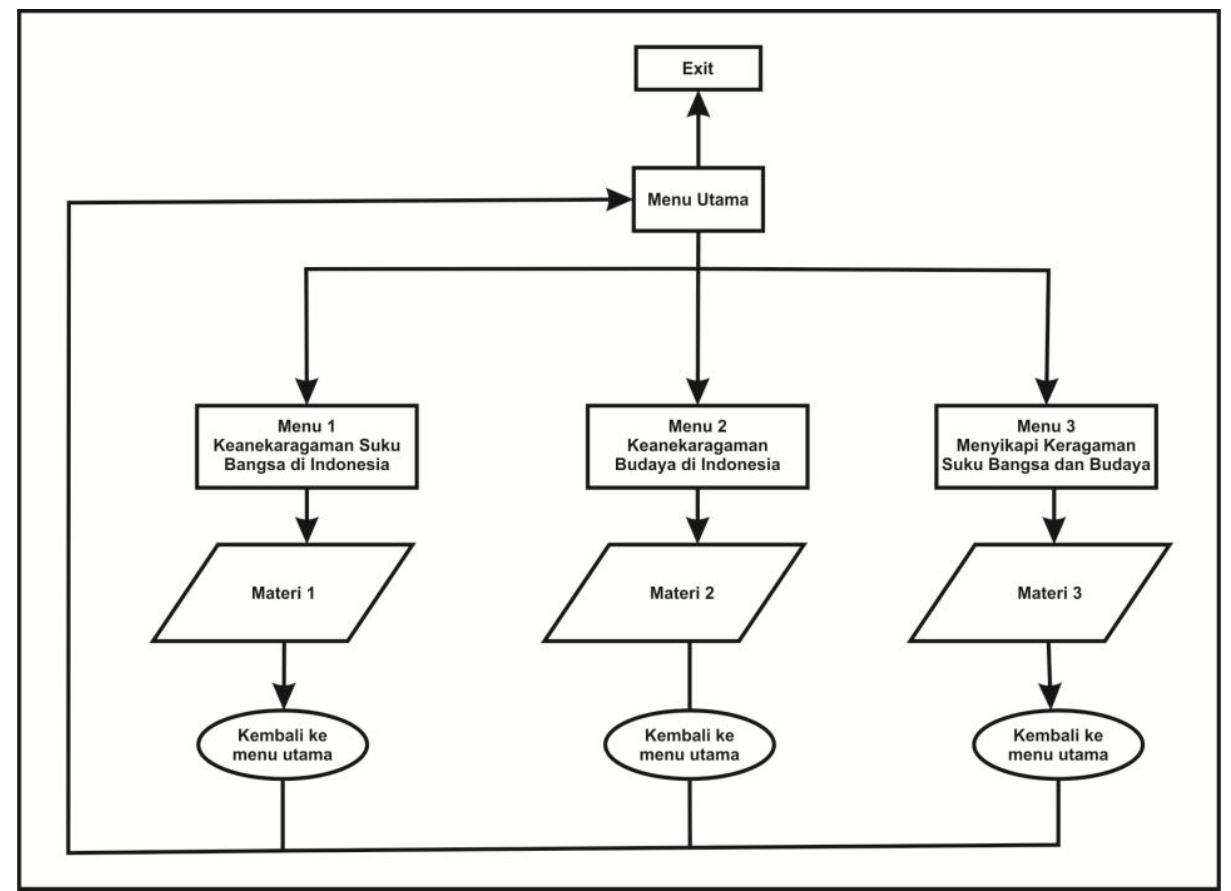

Gambar 2. Flowchart Aplikasi Multimedia Interaktif

Gambar 2 diatas menunjukkan ada dua level dalam multimedia interaktif. Level pertama adalah menu utama, dan level kedua adalah sub menu beserta sajian materi yang terkait. Disetiap sub menu (level kedua) terdapat tombol kembali ke menu utama. Dan pada menu utama terdapat tombol keluar untuk menyelesaikan dan menutup aplikasi multimedia interaktif. Pada menu utama dapat memilih untuk menyelesaikan aplikasi multimedia jika menekan tombol keluar, dan pada tiap-tiap sub menu terdapat tombol untuk kembali ke menu utama.

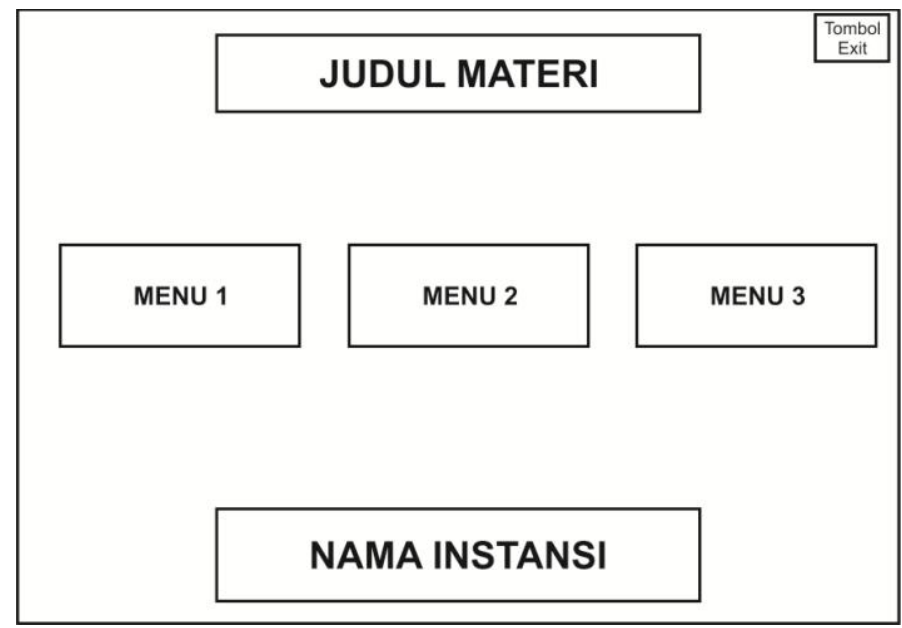

Gambar 3. Tampilan Menu Utama 
Tampak pada menu utama terdapat 3 tombol berada di tengah yang fungsinya adalah untuk masuk ke sub menu materi 1 , sub menu materi 2, dan sub menu materi 3. Di bagian pojok kanan atas terdapat tombol untuk keluar atau menutup aplikasi. Dibagian tengan sebelah atas dan bawah ada elemen teks judul materi dan nama instansi.

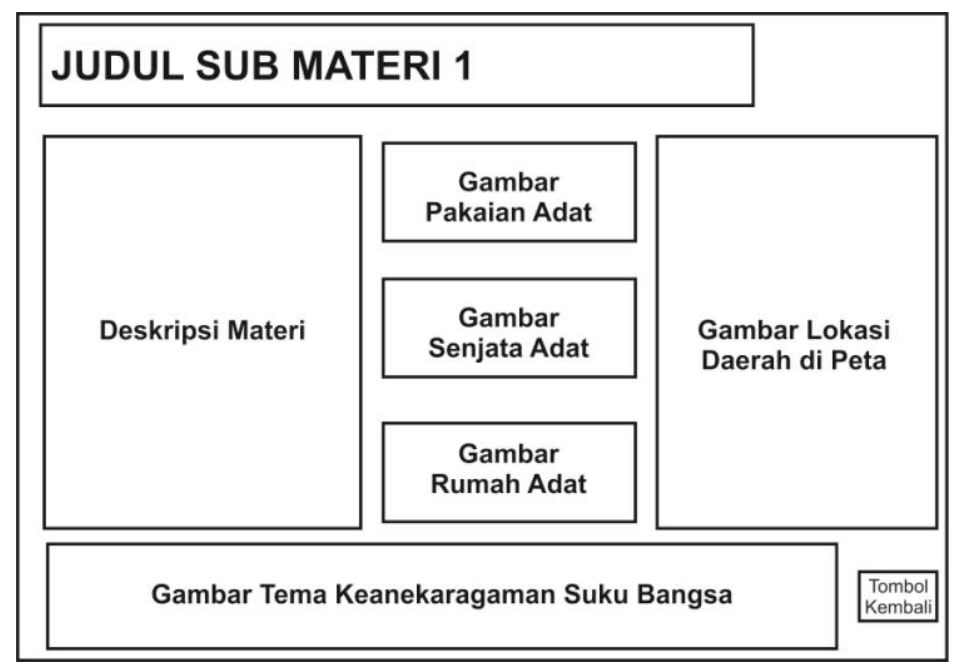

Gambar 4. Tampilan Sub Materi 1

Gambar 4 merupakan tampilan dari sub menu 1, yaitu sub menu untuk materi tentang "Keragaman Suku Bangsa di Indonesia". Pada sub menu ini terdapat bagian deskripsi materi, bagian untuk menampilkan gambar pakaian adat, senjata adat, rumah adat, bagian untuk menampilkan gambar lokasi daerah asal suku bangsa tersebut di peta, dan tombol utuk kembali ke menu utama.

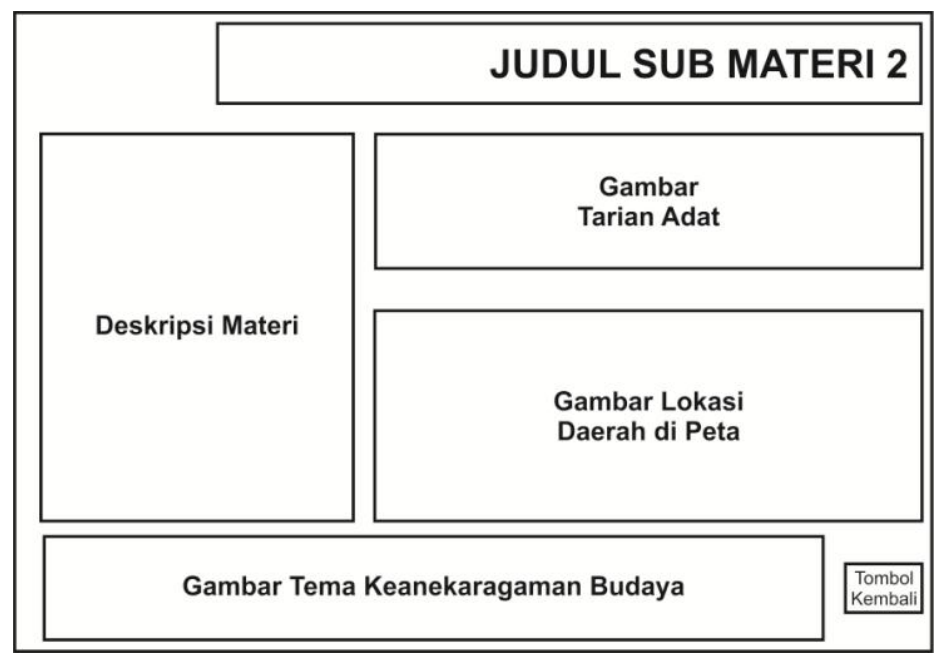

Gambar 5. Tampilan Sub Menu Materi 2 
Gambar 5 merupakan tampilan sub menu materi 2, yaiu sub menu untuk materi tentang "Keragaman Budaya di Indonesia". Di dalamnya terdapat bagian deskripsi materi, gambar tarian adat, gambar lokasi daerah asal, dan tombol untuk kembali ke menu utama.

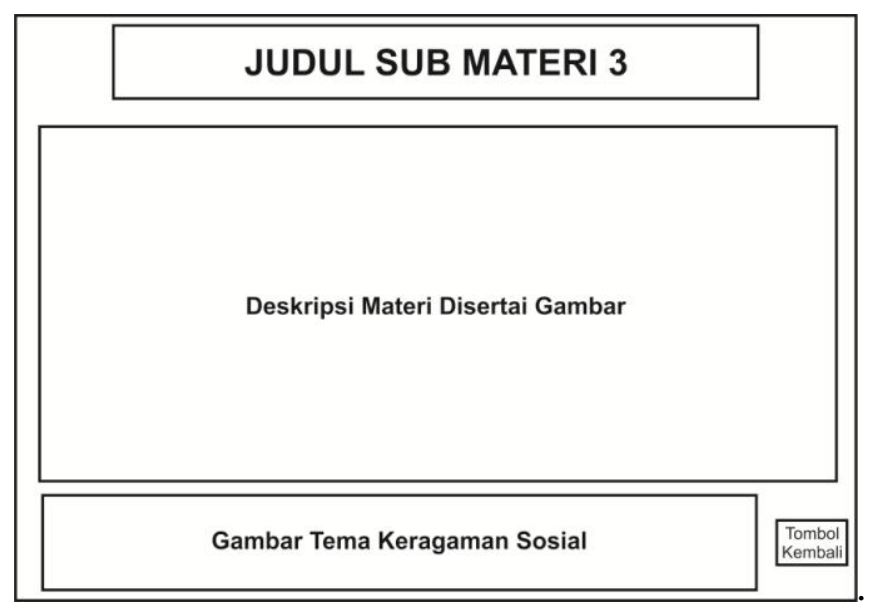

Gambar 6. Tampilan Sub Menu Materi 3

Gambar 6 merupakan tampilan sub menu materi 3, yaitu sub menu untuk materi tentang "Menyikapi Keragaman Suku Bangsa dan Budaya". Pada tampilan sub menu ini hany ada satu bagian untuk menampilkan deskripsi materi lengkap dengan gambarnya, dan terdapat tombol untuk kembali ke menu utama.

\section{Tabel 1. Storyboard Pengembangan Multimedia Interaktif Untuk Pembelajaran IPS di SD Materi "Keragaman Suku Bangsa dan Budaya di Indonesia"}

\begin{tabular}{|c|c|c|}
\hline Scene & Komponen & Keterangan \\
\hline \multirow{3}{*}{ Menu Utama } & \multirow{3}{*}{$\begin{array}{l}\text { Elemen teks dan tombol } \\
\text { interaktif }\end{array}$} & $\begin{array}{l}\text { Elemen teks bagian atas } \\
\text { merupakan judul materi. }\end{array}$ \\
\hline & & $\begin{array}{l}\text { Elemen teks bagian bawah } \\
\text { merupakan identitas. }\end{array}$ \\
\hline & & $\begin{array}{l}\text { Tombol interaktif untuk masuk } \\
\text { ke sub menu materi } 1 / 2 / 3 \text {. }\end{array}$ \\
\hline \multirow{2}{*}{ Sub Menu 1} & \multirow{2}{*}{$\begin{array}{l}\text { Elemen teks, gambar, dan } \\
\text { tombol interaktif. }\end{array}$} & $\begin{array}{l}\text { Elemen teks pada bagian judul } \\
\text { sub materi dan deskripsi materi. }\end{array}$ \\
\hline & & $\begin{array}{llr}\text { Elemen gambar } & \text { untuk } \\
\text { menampilkan pakaian } & \text { adat, }\end{array}$ \\
\hline
\end{tabular}


senjata adat, rumah adat, dan lokasi daerah asal di peta.

Tombol interaktif untuk kembali ke menu utama.

Elemen teks pada bagian judul sub materi dan deskripsi materi.

Elemen teks, gambar, Elemen gambar untuk Sub Menu 2 dan tombol interaktif. menampilkan tarian adat, dan lokasi daerah asal di peta.

Tombol interaktif untuk kembali ke menu utama.

Elemen teks pada bagian judul sub materi dan deskripsi materi.

Sub Menu 3

Elemen teks, gambar, Elemen gambar pada bagian dan tombol interaktif. deskripsi.

Tombol interaktif untuk kembali ke menu utama.

Pada tahap develop, flowchart yang menggambarkan struktur menu dalam multimedia interaktif, rancangan tampilan interface, dan storyboard, diimplementasikan secara real dengan menggunakan perangkat lunak microsoft power point 2013. Hasilnya adalah sebuah multimedia interaktif dalam bentuk file presentasi yang siap digunakan untuk pembelajaran IPS di kelas menggunakan proyeksi infocus.

Pada tahap evaluate, dilakukan evaluasi formatif pada tiap-tiap tahapan model DDD-E. Evaluasi formatif yang dilakukan pada tahap decide menunjukkan bahwa pemilihan multimedia interaktif sebagai bahan pembelajaran IPS di kelas sangat cocok digunakan sebagai media pembelajaran untuk mencapai tujuan pembelajaran yang telah ditentukan. Multimedia interaktif yang notabene berbasis komputer (perangkat lunak microsoft power point) ini juga, cara pengoperasiannya dengan mudah mampu dikuasai oleh para siswa kelas V B. Dan sumber daya di sekolah juga mendukung untuk mengaplikasikan multimedia ini dalam pembelajaran di kelas. Yang kedua adalah evaluasi formatif pada tahap design, 
dimana pada tahap ini tidak dilakukan evaluasi formatif dan hasil rancangan dinyatakan layak untuk digunakan. Kemudian evaluasi formatif pada tahap develop, setelah multimedia interaktif selesai dikembangkan, maka langsung diterapkan dalam pembelajaran di kelas. Hasilnya sangat memuaskan, pembelajaran dapat berjalan dengan baik dan interaktif, dan para siswa terlibat aktif dalam kegiatan pembelajaran. Dalam penerapannya, para siswa dibagi menjadi lima kelompok dan masing-masing kelompok secara bergantian akan maju ke depan untuk membawakan sub-sub materi yang telah disediakan dengan menggunakan multimedia interaktif. Pada saat satu kelompok maju ke depan untuk membawakan materi, satu anggotanya membacakan materi yang terdapat dalam slide presentasi multimedia interaktif yang diproyeksikan melalui infocus, sedangkan anggota lainnya yang mendampingi duduk di bagian depan menghadap kelas sambil meringkas materi yang dibacakan. Demikian juga anggota-anggota kelompok lainnya, duduk di bangku kelompok mereka masing-masing dan meringkas materi yang sedang dibacakan oleh anggota kelompok yang sedang maju ke depan.

Adapun analisis yang dilakukan untuk mengetahui efektifitas produk adalah dengan menganalisis hasil pre-test dan post-test yang telah diikuti siswa. Karena sebelumnya para siswa pernah mengikuti pembelajaran tentang "Keragaman Suku Bangsa dan Budaya di Indonesia" dengan cara yang biasanya atau konvensional (teacher centered dan didominasi ceramah), maka para siswa langsung diberikan soal pre-test untuk melihat kemampuan awal mereka sebelum mengikuti pembelajaran menggunakan multimedia interaktif. Setelah selesai mengikuti kegiatan pre-test, siswa mengikuti pembelajaran tentang "Keragaman Suku Bangsa dan Budaya di Indonesia" menggunakan multimedia interaktif". Pengujian normalitas data menggunakan uji Shapiro-Wilk melalui SPSS menunjukkan bahwa nilai signifikansi shapiro-wilk adalah 0,178 untuk pre-test dan 0,102 untuk posttest, sehingga nilai pre-test dan post-test disini merupakan data yang berdistribusi karena lebih besar dari 0,05, perhatikan gambar7 dibawah ini. 
Tests of Normality

\begin{tabular}{|l|r|r|r|r|r|r|}
\hline & \multicolumn{3}{|c|}{ Kolmogorov-Smirnov $^{\mathrm{a}}$} & \multicolumn{3}{c|}{ Shapiro-Wilk } \\
\cline { 2 - 7 } & Statistic & \multicolumn{1}{c|}{ df } & \multicolumn{1}{c|}{ Sig. } & \multicolumn{1}{c|}{ Statistic } & \multicolumn{1}{c|}{ df } & \multicolumn{1}{c|}{ Sig. } \\
\hline Pre-Test &, 137 & 25 &, 200 &, 943 & 25 &, 178 \\
Post-Test &, 192 & 25 &, 018 &, 933 & 25 &, 102 \\
\hline
\end{tabular}

\section{Gambar 7. Hasil Uji Normalitas Data Pre-test dan Post-test Menggunakan SPSS}

Kemudian analisis dilanjutkan dengan uji t sampel berpasangan. Perhatikan gambar 8 di bawah. Hasil yang diperoleh adalah nilai rata-rata (mean) pre-test sebesar 44,16, sedangkan nilai rata-rata post-test sebesar 84,48. Jumlah siswa yang dijadikan sampel penelitian adalah 25 orang. Nilai standar deviasi (Std. Deviation) pada pre-test 9,385 dan post-test 6,576. Yang terakhir adalah nilai Std. Error Mean, untuk pre-test sebesar 1,877 dan post-test sebesar 1,315. Dikarenakan nilai rata-rata hasil belajar yang diperoleh pada saat pre-test 44,16, yang mana lebih kecil dari post-test 84,48, maka berarti ada perbedaan rata-rata hasil belajar antar pre-test dan post-test. Untuk membuktikan apakah perbedaan ini benar-benar disebabkan oleh pengaruh penggunaan multimedia interaktif atau bukan, maka perlu ditafsirkan hasil uji t sampel berpasangan yang terdapat dalam tabel hasil olahan SPSS (Paired Samples Test) pada gambar 8 .

\begin{tabular}{|c|c|c|c|c|c|}
\hline \multicolumn{6}{|c|}{ Paired Samples Statistics } \\
\hline & & Mean & $\mathrm{N}$ & Std. Deviation & $\begin{array}{l}\text { Std. Error } \\
\text { Mean }\end{array}$ \\
\hline \multirow[t]{2}{*}{ Pair 1} & Pre-Test & 44,16 & 25 & 9,385 & 1,877 \\
\hline & Post-Test & 84,48 & 25 & 6,576 & 1,315 \\
\hline
\end{tabular}

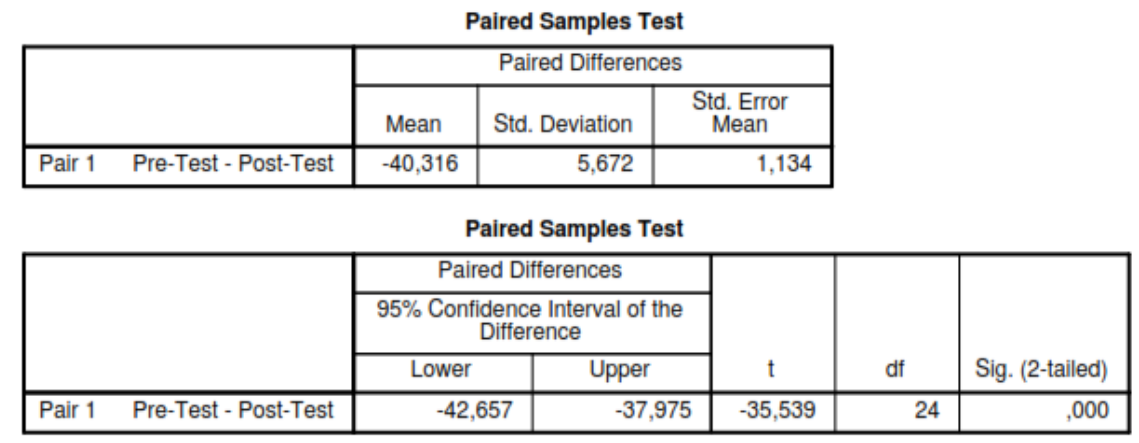

Gambar 8. Hasil Uji T Sampel Berpasangan Pada Nilai Pre-Test dan Post-Test 
Berdasarkan tabel Paired Samples Test yang dihasilkan SPSS, tampak bahwa nilai Sig. (2-tailed) sebesar 0,000 < 0,05 yang berarti H0 ditolak dan Ha diterima. Ini berarti terdapat perbedaan rata-rata antara hasil belajar pre-test dengan post-test yang disebabkan oleh pengaruh penggunaan dari multimedia interaktif dalam kegiatan pembelajaran. Selanjutnya, untuk mengetahui apakah penggunaan multimedia interaktif ini memiliki pengaruh yang besar, sedang, atau kecil terhadap hasil belajar siswa tersebut, maka analisis dilanjutkan dengan menghitung nilai effect size. Hasil perhitungan effect size (d) menunjukkan bahwa nilai effect size adalah sebesar 5,078. Menurut Cohen dalam Dali S. Naga bahwa apabila nilai effect size lebih besar dari 0,8 maka ukuran effect size tergolong besar. Jadi, dapat disimpulkan bahwa penggunaan multimedia interaktif dalam pembelajaran IPS di Sekolah Dasar memiliki pengaruh yang besar dalam meningkatkan hasil belajar siswa.

\section{SIMPULAN}

Model desain pembelajaran DDD-E yang digunakan dalam penelitian ini telah menghasilkan sebuah produk pembelajaran berupa multimedia interaktif yang efektif untuk digunakan dalam pembelajaran IPS di Sekolah Dasar. Penerapan multimedia interaktif dalam kegiatan pembelajaran IPS di SDN 06 Pontianak Kota ini, dipadukan dengan model pembelajaran kontekstual untuk menciptakan proses pembelajaran yang efektif, efisien, berorientasi pada konsep student centered, keterlibatan siswa secara aktif, dan memberikan pengalaman belajar langsung kepada siswa. Hasil analisis uji t sampel berpasangan dan perhitungan effect size menunjukkan bahwa terdapat pengaruh yang besar dari penggunaan multimedia interaktif dalam pembelajaran IPS di SDN 06 Pontianak Kota terhadap hasil belajar siswa.

\section{DAFTAR PUSTAKA}

Anonim. 2013. "Piaget: Tahap Operasional Konkret". dalam https://www.asikbelajar.com/piaget-tahap-operasional-konkre/. Diakses Tanggal 7 Agustus 2019. 
Asrori, M. 2015. Perkembangan Peserta Didik: Pengembangan Kompetensi Pedagogis Guru. Yogyakarta: Media Akademi.

Dali S. Naga. "Ukuran Efek Dalam Laporan Hasil Penelitian" dalam http://dali.staff.gunadarma.ac.id/Publications/files/399/Publications/files/399/ 4861-aARCHE.doc. Diakses Tanggal 9 Agustus 2019, pukul 10:25 WIB.

Getut, Pramesti. 2014. Statistika Lengkap Secara Teori dan Aplikasi Dengan SPSS 23. Jakarta: PT. Elexmedia Komputindo.

HUMAS. 2016. "Analisis Data Statistik Inferensial" dalam https://penalaranunm.org/analisis-data-statistik-inferensial/. Diakses Tanggal 8 Agustus 2019.

Raharjo, Sahid. 2015. "Uji Normalitas Data Rumus Shapiro-Wilk dengan SPSS" dalam https://www.konsistensi.com/2013/04/uji-normalitas-data-denganspss.html. Diakses Tanggal 9 Agustus 2019.

Raharjo, Sahid. 2017. "Cara Uji Paired Sample T-Test dan Interpretasi dengan SPSS" dalam https://www.spssindonesia.com/2016/08/cara-uji-pairedsample-t-test-dan.html. Diakses Tanggal 9 Agustus 2019.

Rizki. 2019. "Teknik Analisis Data Kualitatif, Kuantitatif, Menurut Para Ahli" dalam https://pastiguna.com/teknik-analisisdata/\#A_Teknik_Analisis_Data_Kuantitatif. Diakses Tanggal 8 Agustus 2019.

Tegeh, I Made. Jampel, I Nyoman. Pudjawan, Ketut. 2014. Model Penelitian Pengembangan. Yogyakarta: Graha Ilmu. 